\title{
Dominasi Soeharto, Monopoli Usaha Oleh Birokrat Dan Pengusaha
}

\author{
Muhammad Zoher Hilm \\ email..mzoherhilmi@unu-ntb.ac.id
}

\begin{abstract}
Abstrak. Tujuan artikel ini ialah untuk menjelaskan kebijakan ekonomi Orde Baru dan memberikan penjelasan dan pemahaman tentang perubahan sosial dan ekonomi masyarakat Indonesia pada zaman Orde Baru. Sehingga melalui artikel ini pula mampu memberikan pemahaman terkait dominasi Soeharto, monopoli usaha oleh birokrat dan pengusaha, dikarenakan setiap kebijakan yang diambil dalam pemerintahan Orde Baru ada dominasi di dalamnya.
\end{abstract}

Kata Kunci: Dominasi Soeharto, Monopoli Usha, Birokrat, dan Pengusaha

Abstract. The purpose of this article is to explain the economic policies of the New Order and provide an explanation and understanding of the social and economic changes in Indonesia in the New Order era. So that through these articles is also able to provide related knowledge Soeharto dominance, business monopoly by bureaucrats and businessmen, due to any measures taken in the government of Suharto's New Order dominance in it.

Keywords: Soeharto Dominance, Business Monopoly, Bureaucrat, and Businessman

\section{PENDAHULUAN}

Orientasi perekonomian Indonesia yang terus mengalami perubahan semenjak Indonesia memproklamasikan kemerdekaannya. Begitu juga dengan sifat perekonomian dari tertutup hingga sifatnya terbuka pada saat Orde Baru. Pada awal kemerdekaan tidak sepenuhnya pemerintah pada waktu itu memfokuskan diri pada pembangunan ekonomi, karena Indonesia pada saat itu meskipun sudah dinyatakan merdeka tidak berarti dalam praktiknya Indonesia sudah bebas dari Belanda. Begitu halnya Indonesia pada saat itu Indonesia dilanda gejolak politik dan pemberontakan di dalam negeri yang tersebar di berbagai daerah seperti di Sumatra dan Sulawesi. Alasanalasan seperti itulah yang menjadikan kondisi perekonomian Indonesia mengalami keterpurukan, meskipun sempat mengalami pertumbuhan selama dekade 1950-an setelah itu turun drastis (Tambunan, 2015: 17).

Berbeda halnya dengan pada waktu tombak kepemimpinan di bawah Soeharto yang dikenal dengan pemerintahan Orde Baru. Keadaan perekonomian yang diwariskan oleh pemerintahan Orde Lama yang sangat memprihatinkan, bisa dibilang berubah signifikan pada waktu Orde Baru yaitu dengan keaadaan perekonomian
Indonesia yang meningkat drastis. Pemerintahan Orde Baru pada waktu itu ditujukan kepada peningkatan kesejahteraan masyarakat melalui pembangunan ekonomi dan sosial ditanah air. Begitu juga pada saat Orde Baru, menjalin kerja sama dengan pihak Barat yang sempat terhenti pada awal kemerdekaan dan menjauhi pengaruh ideologi komunis (Tambunan, 2015: 21).

Di dalam pemerintahan Orde Baru banyak terjadinya perubahan baik dalam bidang ekonomi maupun sosial. Sehingga bisa dikatakan bahwa Soeharto pada waktu itu berhasil membangun kembali perekonomian Indonesia yang sempat terpuruk, mampu bangkit kembali dan memiliki tujuan yang jelas dan tegas. Soeharto dengan kemauan politiknya yang kuat, stabilitas politik dan ekonomi, sumber daya manusia yang lebih baik, dengan sistem perekonomian yang berorientasi ke Barat dan kondisi ekonomi dan politik yang lebih baik pada waktu itu membuatnya dalam membangun perekonomian dapat berjalan dengan baik (Tambunan, 2015). Meskipun pada zaman Orde Baru perekonomian dan perubahan sosial berjalan positif pada tahun sebelum terjadinya krisis ekonomi, tidak berarti bahwa pada zaman tersebut tidak ada dampak negatifnya, melainkan pada saat itu juga 
fundamental perekonomian Indonesia sangat rapuh dan biaya ekonomipun tinggi mampu membuat perubahan dalam bidang ekonomi yaitu laju pertumbuhan ekonomi yang tinggi.

Begitu juga dengan yang dikatakan Hadi dan Kasuma (2012) yang dikutip dari Saidi, (2007:161) meskipun diakui bahwa perekonomian pada masa Orde Baru mengalami peningkatan drastis, tetapi semua itu tidak merata di setiap daerah, dan itu yang memicu terjadinya kecemburuan sosial. Begitu juga terjadi pada masa itu pembangunan berpihak kepada pemilik modal yang juga mengakibatkan kesenjangan yang tajam terjadi antara masyarakat miskin dan masyarakat yang kaya.

Pada zaman Orde Baru tersebut juga banyak terjadi gejolak, baik dalam bidang politik maupun dalam bidang perekonomian. Itulah yang menyebabkan Soeharto jatuh, begitupun dengan pemerintahannya yang dibangun selama 32 tahun menjadi tumbang. Di dalam pertumbuhan ekonomi yang terjadi dan perubahan sosial yang meningkat tidak bisa dipungkiri terdapat dominasi Soeharto di dalamnya. Tidak bisa dipungkiri juga bahwa dalam pemerintahan Orde Baru Soeharto lah yang paling berperan dalam segala kebijakan yang diambil oleh penguasa-penguasa pada waktu itu.

Oleh sebab itu, perlu kiranya dalam tulisan ini penulis sajikan beberapa pembahasan terkait dengan dominasi Soeharto dalam kebijakan ekonomi, politik sehingga berdampak pada perubahan sosial dan ekonomi masyarakat Indonesia pada waktu itu. Sehingga penulis membahas berbagai rumusan masalah yaitu bagaimana kebijakan ekonomi Orde Baru? dan bagaimana perubahan sosial dan ekonomi masyarakat Indonesia pada waktu itu?. Sehingga melalui sajian dalam tulisan ini mampu memberikan pemahaman terkait dominasi Soeharto dalam setiap kebijakan ekonomi dan perubahan sosial dan ekonomi masyarakat.

\section{PEMBAHASAN}

Mengenai kebijakan dalam setiap langkah pemerintahan Orde Baru, Soeharto mengambil peran penting di dalamnya, dengan begitu Soeharto mendominasi dalam setiap kebijakan yang dambil oleh pemerintahan pada waktu itu. Sehingga tidak mengherankan jika kroni-kroni Soeharto pada waktu itu mendominasi juga dalam beberapa hal-hal penting. yang seharusnya Soeharto pada waktu itu memperhatikannya dengan jelas, karena pada akhirnya mereka-merekalah yang menyebabkan runtuhnya benteng pertahanan Pemerintahan Orde Baru. Sehingga dalam pembahasan ini menyajikan beberapa hal diantaranya:

\section{Kebijakan Ekonomi Orde Baru}

Kebijakan ekonomi Orde Baru yang diambil oleh Soeharto dalam memperbaiki perekonomian Indonesia yang jatuh salah satunya terjadi inflasi yang sangat tinggi warisan dari pemerintahan Orde Lama pada zaman Soekarno, yaitu dengan melakukan berbagai langkah guna untuk memajukan perekonomian negara atau membanguan kembali perekonomian Indonesia yaitu dengan melakukan stabilitas dan rehabilitas ekonomi, kerjasama luar negeri, dan melakukan pembangunan nasional dengan memberlakukan program pembangunan lima tahun.

Dengan ketiga langkah tersebut, inflasi yang menimpa negara Indonesia bisa terselesaikan dalam waktu yang relatif singkat. Sehingga di bawah kepemimpinan pada tahun awal-awal Soeharto ekonomi Indonesia sangat pesat karena Soeharto dalam memimpin negara beliau fokus pada pembangunan ekonomi. Hal itu terlihat ketika dilakukannya program pembangunan lima tahun atau yang disebut Pelita, dengan perogram tersebutlah maka Soeharto disebut sebagi bapak pembangunan.

a. Stabilitas dan rehabilitas ekonomi

Pemerintahan soeharto dalam melakukan stabilitas dan rehabilitas ekonomi merupakan program pemerintah yang diarahkan pada upaya penyelamatan ekonomi nasional. Stabilitas ekonomi merupakan mengendalikan inflasi agar harga barangbarang tidak melonjak terus. Sedangkan rehabilitas ekonomi merupakan perbaikan secara fisik sarana dan prasarana ekonomi.hakikat dari kebijakan ini merupakan pembinaan sistem ekonomi 
berencana yang menjamin berlangsungnya demokrasi ekonomi ke arah terwujudnya masyarakat adil dan makmur berdasarkan pancasila (Sudirman, 2014: 426).

Melalui rehabilitasi disertai dengan rencana pembangunan lima tahun ini lah laju inflasi mampu dibendung, dan laju pertumbuhan ekonomi semakin tumbuh. Kebijakan stabilitas dan rehabilitas ekonomi yang diambil Soeharto ini mampu membuat negara bangun dari keterpurukan yang selama hampir lebih dari 10 tahun terakhir mengalami keterpurukan dalam berbagi bidang.

Di dalam melakukan kebijakan Stabilitas dan rehabilitas ekonomi yang dilakukan ialah melakukan Kabinet Ampera yang mengacu pada ketetapan MPRS melakukan berbagai langkah. a) mendobrak kemacetan ekonomi dan memperbaiki sektorsektor yang menyebabkan terjadinya kemacetan ekonomi tersebut. Adapun yang menyebabkan terjadinya kemacetan ekonomi sebagai berikut: rendahnya penerimaan Negara, tinggi dan tidak efisiennya pengeluaran Negara, terlalu banyak dan tidak efisiennya ekspansi kredit bank, terlalu banyak tunggakan hutang luar negeri, dan penggunaan devisa bagi impor yang sering kurang berorientasi pada kebutuhan prasarana. b) debirokrasi untuk meperlancar kegiatan perekonomian. c) berorientasi kepada kepentingan produsen kecil (Sudirman, 2014).

b. Kejasama Luar Negeri

Kebijkan kerjasama luar negeri dilakukan oleh pemerintah dalam rangka Indonesia pada saat Orde Lama utang luar negerinya sangat parah bahkan sampai tidak bisa dilunasi sampai dengan jangka waktu yang telah ditetapkan. Sehingga dengan kebijakan luar negeri ini pemerintah melakukan penundaan pembayaran terhadap utang yang melilit Negara (Sudirman, 2014: 427). Oleh karena itu pemerintah melakukan program reformasi dalam pembangunan dalam negeri dan pembanguan ekonomi, dan Soeharto memperoleh tanggapan yang positif dari negara-negara luar. Melalui pelaksanaan program reformasi tersebut memberikan angin positif dengan dilakukan penjadwal ulang utang luar ngeri (Wanandi, 2014: 124).

Disamping itu, pemerintah melakukan asimilasi orang-orang Cina dengan memutuskan hubungan dengan leluhur dengan penggantian nama bagi WNI yang memakai nama Cina, larangan memperdagangkan dan mengedarkan segala jenis barang negara-negara luar. Dengan melakukan program reformasi tersebut memberikan angin positif dengan dilakukan penjadwal ulang utang luar ngeri cetakan dalam bahasa Cina, sekolah-sekolah Cina ditutup dan semua anak sekolah harus pindah ke pengajaran yang disampaikan dalam bahasa Indonesia. Koran berbahasa Cina juga dilarang terbit. Organisasi Cina tertentu dilarang, apakah itu organisasi kaum totok seperti perhimpunan masyarakat berdasarkan tempat asal atau organisasi kaum peranakan seperti BAPERKI, sebuah organisasi untuk menggalakkan kewarganegaraan Indonesia dan membela kepentingan kaum minoritas (Suhandinata, 2009: 143).

Langkah yang dilakukan oleh pemerintahn untuk melakukan penundaan dalam pembayaran inilah dengan cara mengikuti perundingan dengan negara-negara kreditor di Tokyo, Jepang pada tanggal 19-20 September 1966. Perundingan dilanjutkan di Paris, Prancis dan dicapai sebuah kesepakatan. Kesepakatan terbut sebagaimana yang telah dikatakan sebelumnya yaitu terjadinya kesepakatan dalam hal penundaan pembayaran hutang luar negeri. Berbagai perundingan yang dilakukan oleh pemerintah guna utuk menjalin kerja sama luar negeri yang baik untuk pembangunan perekonomian negara, melalui kerjasama ini juga pemerintah memanfaatkan untuk meminta bantuan luar negeri guna memenuhi kebutuhan dalam negeri atau memberikan bantuan dengan syarat lunak (Sudirman, 2014: 427). Melalui perundingan yang dilakukan oleh pemerintah akhirnya negara memperoleh bantuan luar negeri. Sejak itulah pembangunan di negara mulai berkembang dan pemerintah mulai dibebani oleh kepentingan luar yang merasuk ke dalam pemerintahan Indonesia.

$$
\text { c. Pembanguan Nasional }
$$


Pada masa Orde Lama pemerintah fokus pada bagaimana cara mempertahankan kemerdekaan dan menjaga politik dalam negeri sehingga pembanguan dalam bidang ekonomi bisa dikatakan disepelekan. Akibabatnya terjadi berbagi goncangan dalam bidang ekonomi tidak bisa diselesaikan oleh pemerintah Orde Lama, karena pada saat ini mungkin belum terpikir oleh pemerintah kalau negara kuat dalam bidang ekonomi maka negara akan maju dan mampu bersaing dengan luar negeri.

Pada saat pemerintaha Orde Lama berkuasa banyak meninggalkan masalah dalam bidang ekonomi. Ini semua menjadi pekerjaan rumah bagi pemerintahan Orde Baru yang merupakan pengganti dari pemerintahan Orde Lama. Dengan ditinggalkannya kondisi perekonomian yang rapuh oleh pemerintahan Orde Lama, pemerintah Orde Baru harus berpikir dan membolak-balikkan kepala mencari jalan keluar guna memecahkan masalah yang telah diwariskan oleh pemerintahan sebelumnya.

Berdasarkan hal itulah, pada masa Orde Baru pembangunan mulai ditingkatkan. Sehingga dengan hal tersebut juga presiden Soeharto dijuluki bapak pembangunan Indonesia. Adapaun tujuan dari program tersebut adalah demi tercapainya masyarakat yang adil dan makmur berdasarkan pancasila dan UUD 1945 (Sudirman, 2014: 414). Arah dari kebijaksanaan ekonominya adalah pembangunan segala bidang. Pedoman pembangunan nasionalnya adalah trilogi pembangunan dan delapan jalur pemerataan. Inti kedua pedoman tersebut adalah kesejahteraan bagi semua lapisan masyarakat dalam suasana politik dan ekonomi yang stabil (Sudirman, 2014: 428).

Bahkan setelah dijuluki sebagai bapak pembangunan, $\begin{array}{cr}\text { Soeharto } & \text { terus } \\ \text { gelar sebagai } & \text { bapak } \\ \text { sekalipun } & \text { dalam }\end{array}$ $\begin{array}{lcc}\text { mempertahankan } & \text { gelar } & \text { bapak } \\ \text { pembangunan } & \text { sekalipun } & \text { dalam }\end{array}$ pelaksanaannya beliau sandarkan kepada keluarga dan kroni-kroninya. Bahkan terus berusaha menepis anggapan kronisme dan nepotisme ditubuh kebijakan yang telah beliau putuskan (Edward, dkk, 2000: 98). Bahkan di dalam perjalanan Soeharto terus mengesampingkan nepotisme yang dilakukannya. Yang beliau tidak menyadarinya suatu hari itulah yang akan merobohkan bangunan kekuasaannya yang telah dinagun selama 32 tahun lamanya.

Di dalam pelaksanaannya, pembangunan nasional tersebut dilakukan melalui dua tahap, pertama dilakukan dalam jangka panjang yang mencakup periode 25 sampai 30 tahun. Kedua dilakukan dalam jangka pendek, mencakup periode 5 tahun disebut dengan Pelita. Setiap Pelita selalu berkaitan atau saling berkesinambungan antara Pelita satu dengan Pelita yang lainnya (Sudirman, 2014: 428).

Kebijkan pembangunan nasional yang dilancarkan oleh pemerintahan Orde Baru bisa dikatakan berjalan mulus, sehingga dengan diberlakukan program tersebut sang pendiri disebut sebagai bapak pembanguanan Indonesia. Program tersebut juga mengantarkan Indonesia menjadi swasembada beras. Program tersebut juga mampu diterapkan samapi 6 kali selama Soeharto menjadi penguasa di negara Indonesia. Yang dikenal dengan Pelita I, Pelita II, Pelita III, Pelita IV, Pelita V, dan Pelita VI.

Disamping keitiga kebijakan yang dilakukan oleh pemerintah Orde Baru dalam bidang ekonomi, semua itu tidak bisa terlepas dari masalah politik luar negeri yang dilakukan. Dengan dilakukan politik luar negeri ini mempermudah negara Indonesia dalam berkomunikasi dengan negara lain, karena sebelumnya Indonesia di bawah kepemimipnan Orde Lama Indonesia pernah terjadi konfrontasi Orde Lama.

Kebijakan-kebijakan yang dilakukan pemerintah Orde Baru dalam politik luar negeri ialah dengan kembalinya menjadi anggota PBB karena pada masa Soekarno pernah keluar dari PBB, dan kebijakan yang kedua ialah melakukan normalisasi hubungan dengan negara lain (Singapura, Malaysia Dan RRC). Melalui politik luar negeri inilah Soeharto dapat menjalin kerja sama dalam berbagai bidang termasuk mendapatkan bantuan luar negeri dalam bentuk pinjaman.

Pemerintah melakukan langkah politik luar negeri termasuk kembali lagi menjadi anggota PBB karena pemerintah sadar bahwa banyak manfaat yang akan diperoleh menjadi 
anggota PBB semenjak tahun 1955-1964. Dengan keputusan tersebut Indonesia disambut baik oleh negara-negara Asia lainnya bahkan oleh PBB sendiri, bahkan dari pihak Indonesia Adam Malik dipilih sebagai Ketua Majelis Umum PBB untuk masa sidang 1974. Dengan mulai dari menjadi anggota PPB lagi Indonesia dapat memulihkan kembali hubungan dengan sejumlah negara seperti Inidia, Thailand, Australia, dan negara-negara lainnya (Sudirman, 2014: 422).

Pemerintah di bawah kepemimpinan presiden Soeharto, Soeharto merubah haluan yaitu berpihak ke Barat yang semenjak di bawah kepemimpinan Soekarno yang anti Barat, Soeharto berbeda pandangan dengan mengubah haluan yaitu dengan menjalin hubunan dengan negara-negara Barat. Dikarenakan Soeharto sadar bahwa negaranegara Baratlah yang akan mampu membantu dalam mengatasi krisi ekonomi yang melanda negara. Begitu juga secara ideologis juga Soeharto lebih dekat dengan Amerika Serikat karena sama-sama menentang kaum komunisme. Disamping itu juga Soeharto membutuhkan Amerika Serikat secara ekonomis dan strategi politik untuk menagkal usaha China dalam menentukan masa depan Asia Tenggara (Wanandi, 2014: 224).

Sementara itu melaui kebijakan politik luar negeri Indonesia yaitu terkait dengan normalisasi hubungan dengan Singapura, Malaysia Dan RRC. Dengan Singapura terjadi kesepakatan pada tanggal 2 Juni 1966, dengan Malaysia pada tanggal 29 Mei sampai 1 Juni 1966 yang menghasilkan perjanjian Bangkok, dan dengan RRC pada tanggal 1 Oktober 1967 dengan membuka hubungan diplomatik karena keikut campuran dalam memberikan bantuan kepada G $30 \mathrm{~S}$, dan memberikan perlindungan kepada tokoh-tokoh G $30 \mathrm{~S}$ (Sudirman, 2014: 423). Melalui kebijakan politik luar negeri inilah pemerintah dapat melakukan kerjasama dengan berbagi negara didunia, sehingga membuka diri tersebut pemerintah memperoleh berbagai macam kemudahan dalam berbagai bidang sosial ekonomi, khususnya dalam bidang ekonomi Indonesia mampu untuk membangun negara di bawah kepemimpinan Orde Baru itu semua akibat dari politik luar ngeri yang dilakukan oleh pemerintah.

Melalui politik luar negeri ini juga pemerintah berhasil menarik kembali negara luar berinvestasi lagi di negara Indonesia terutama negara barat, yang selama pemerintahan Orde Lama di bawah kepemimpinan Soekarno pernah terhenti. Dikarenakan Soeharto juga tidak memiliki banyak pilihan karena keterbatasan yang dimiliki oleh Indonesia selama dipimpin oleh Soekarno, sehingga Soeharto melakukan program reformasi dan program tersebut di dukung oleh Masyarakat Internasional (Wanandi, 2014: 124).

Begitu juga selanjutnya Wanandi (2014: 124) menjelaskan bahwa pemerintah Soeharto pada awal pemerintahannya lebih banyak memfokuskan diri pada pembanguan dalam negeri, akan tetapi berselang waktu Soeharto membuka perekonomian negara dengan ikut serta dalam ASIAN, mulai membuka pasar, membangun industri ringan, pertumbuhan yang mengandalkan ekspor dan mengundang investor asing. Begitu itu juga Indonesia sangat terbuka dan mulai mengelola nilai rupiah yang mengambang.

Sebelumnya pemerintah Soeharto belum memperhatikan masalah luar negeri, akan tetapi setelah ia merasa bahwa ia berhasil dalam mengelola masalah dalam negeri baru memperhatikan masalah luar negeri. Hal ini ASEAN lah yang menjadi pertama kalinya mengakuinya sebagai seorang pemimpin. Pada akhir tahun 1980-an perekonomian di kawasan ASEAN tumbuh pesat dan dengan sendirinya para kroni dan anggota keluarga Soeharto berubah menjadi kaya, dan dari dorongan menteri, Soeharto membuka ekonomi Indonesia. Sebab inilah pada tahun 1993 presiden Soeharto mendapat julukan sebagai pendekar pasar bebas (Wanandi, 2014: 369).

Sukses yang pailing menonjol dari semua keputusan kebijakan luar negerinya adalah Deklarasi Bogor tahun 1994 dari KTT APEC. Orang tidak menyangka ia (Soeharto) akan mendukung gagasan perdagangan bebas di kawasan, dengan batas waktu 2010 bagi negara maju dan 2020 bagi negara berkembang. Soeharto membuka ekonomi 
Indonesia selebarnya dan menyadari bahwa Indonesia diterima di dunia Internasional. Ia merasa tersanjung karena merasa mengubah Indonesia dari ekonomi yang sangat tertutup menjadi salah satu yang paling terbuka dalam kurun waktu satu atau dua dekade. Semua memuji Soeharto. GNB Dan APEC adalah masa Soeharto bener-bener tampil bersinar dalam hubungan Internasional (Wanandi, 2014: 368).

Politik luar negeri yang dilakukan oleh pemerintah pada masa Orde Baru memiliki dampak positif dan dampak negatif, begitu juga dengan kebijkan yang dilakukan dalam bidang ekonomi memiliki dampak positif dan negatifnya. Dampak positif dan negatif memang tetap ada didalam setiap kebijakan, atau terjadi pro dan kontra itu merupakan hal yang tidak bisa dipisahkan dalam setiap keputusan. Dampak positif dari kebijakan yang dilakukan Soeharto tidak mampu menolongnya dalam mempertahankan kekuasaannya, karena terjadi berbagai goncangan dari berbagai faktor bahkan seluruh sistem Orde Baru yang selama ini beliau bangun ambruk dari dalam, karena pendukungnya lari menghianatinya.

$$
\text { Terjadinya KKN ditubuh }
$$

pemerintahan, hal inilah yang paling mendasar yang meruntuhkan kepemimpinan Soeharto. Mungkin soeharto karena terlalu berlebihan dalam memperhatikan keluarganya terutama anak-anaknya sehingga anakanaknya dan orang dekatnya menjadi dasar robohnya bangunan pemerintahan yang selama 32 tahun dibangun dan dikuasainya. Hal ini tidak mengherankan karena Soeharto sepertinya lebih mementingkan kepentingan keluarganya dari pada kepentingan publik. Begitu juga dengan orang dekatnya atau kepercayaannya juga beliau jauhi akibat orang dekatnya menentang anak-anaknya. Hal ini pernah terjadi ketika Benny Moerdani menyampaikan kekhawatiran Ali Moertopo kepada Soeharto tentang putra-putri Soeharto yang setelah dewasa terjun dalam dunia bisnis sulit dikendalikan. Mereka menggunakan posisi mereka sebagai anak-anak presiden untuk menguasai macam-macam monopoli yang mengacaukan dunia industri. Ali Moertopo berpendapat ini salah dan ia khawatir bahwa praktek-praktek mereka akan membahayakan Orde Baru, dan situasinya semakin parah dimna-mana ada anak Pesiden Soeharto, kalau begini terus, tidak saja mengancurkan Soeharto, republik ini pun bisa hancur (Wanandi, 2014: 301).

Hal inilah kemudian oleh Benny Moerdani disampaikan kepada Soeharto akhirnya Soeharto menjauhi Benny Moerdani, dan Benny juga pernah menahan paspor Sigit Harjojudanto putra sulung Soeharto agar tidak lagi berjudi di luar negeri dan juga pernah mengingatkan putri sulung Soeharto. Mungkin karena sering dikata-katain sangat pedas oleh Benny akhirnya mereka melapor kepada Soeharto. Hal itu terbukti dari penjelasan yang dikemukakan oleh Edward, dkk (2000: 22) yaitu dengan tatanan ekonomi Indonesia dirusak oleh kroninya sendiri, karena Soeharto tidak pernah mau menerima nasihat dari orang dekatnya mengenai keluarga dan kroni-kroninya. Karena itu maka perekonomian Indonesia menjadi terpuruk dan bahkan komunitas keuangan internasional diputuskan secara fatal oleh kroni-kroninya.

Bahkan Edward, dkk (2000: 56) menjelaskan pula bahwa sebelumnya indoneisa sangat dipuji dan dielukan karena keberhasilan dalam melakukan program reformasi dalam bidang perekonian bahkan lembaga keuangan internasional seperti IMF dan Bank Dunia pernah memberikan pujian kepada Indonesia karena perekonomian Indonesia yang bisa dikatakan sangat berkembang pesat. Akan tetapi sekarang IMF dan Bank dunia hampir tidak mempercayai Indonesia dalam mengembalikan utang pinjaman karena terjadi keterpurukan bahkan terjadi pertikaian terhadap dua lembaga internasional tersebut.

Di sisi lain dalam hal program reformasi yang dilakukan oleh pemerintah, pemerintah sudah merasa siap untuk melakukan program reformasi tersebut, bahkan pejabat senior kedua IMF pernah menyatakan bahwa pemerintah Indonesia merupakan kelompok yang menginginkan reformasi. Akan tetapi itu merupakan keinginan yang tidak didukung oleh kalangan bisnis yang tampaknya tidak cukup kuat dalam melakukan pertentangan atau dalam 
posisi menentang (Edward, dkk, 2000: 2425).

\section{Perubahan Sosial dan Ekonomi}

Pada masa demokrasi terpimpin, negara bersama aparat ekonominya mendominasi seluruh kegiatan ekonomi hingga mematikan potensi dan kreasi unitunit ekonomi swasta. Sehingga pada permulaan Orde Baru, program pemerintah berorientasi pada usaha penyelamatan ekonomi nasional, terutama usaha mengendalikan tingkat inflasi, penyelamatan keuangan negara, dan pengamanan kebutuhan pokok rakyat. Tindakan ini dilakukan karena adanya kenaikan harga pada awal tahun 1966 yang menunjukkan tingkat inflasi kurang lebih 650\% setahun (Sudirman, 2014: 424). Perubahan sosial ekonomi di sini yang dimaksud ialah perubahan bagaimana penghidupan rakyat, penyediaan pendidikan, dalam bidang keagamaan dan dalam perubahan dalam bidang ekonomi.

Penghidupan rakyat Indonesia pada masa Orde Baru bisa dikatakan berubah atau penghidupannya lebih baik bila dibandingkan dengan masa kolonial dan masa demokrasi terpimpin. Pada masa Orde Lama rakyat lebih baik dengan diperhatikannya mulai dari kesehatannya oleh pemerintah hal ini sudah menjadi terbukti pada masa pemerintahan Orde Baru (Ricklefs, 1991: 433). Perubahan sosial juga bisa dilihat dari semakin banyaknya rakyat Indonesia yang mampu membaca atau melek huruf, karena pada masa Orde Baru penyediaan pendidikan bagi rakyat semakin luas, terutama dalam pengusaan bahasa nasional. Sehingga secara tidak langsung dapat memberikan efek samping terhadap semakin langgengnya kekuasaan Orde Baru, karena semakin banyak masyarakat yang mengerti dengan surat kabar yang menyebar, karena surat kabar tersebut juga sudah dimonopoli oleh pemerintah Orde Baru (Hadi dan Kasuma, 2012). Adanya pengawasan kontrol tersebut akhirnya dapat memberikan keuntungan bagi pemerintah dengan memberikan penyediaan ruang pendidikan bagi rakyat. Sehingga mereka lebih mengerti dalam menggarap lahan mereka dan lain sebagainya.
Pada masa Orde Baru seperti yang dijelaskan oleh Ghazali (2004) yang dikutif oleh Hadi dan Kasuma (2012) mengatakan bahwa media massa pada waktu itu sendiri sengaja diatur oleh Soeharto untuk memiliki fungsi ganda atau dikenal dengan berwajah dua. Fungsi-fungsi tersebut ialah pertama menjadi industri yang mampu mendongkrak kemajuan iklim investasi ke arah yang lebih baik. Sedangkan fungsi kedua dari media massa saat itu ialah menjadi partner pembangunan bagi pemerintah.

Begitu juga dengan perubahan sosial dalam bidang keagamaan, dengan pada masa kolonial terjadi kekerasan batin yang karena antar agama kurangnya toleransi diantara mereka, akan tetapi semenjak Orde Baru antar umat beragama toleransi smakin kuat. Yang biasanya terjadi ketegangan dan konflik diantara umat beragama terutama antara umat islam dan Kristen sering terjadi, akan tetapi semenjak Orde Baru ketegangan dan konflik tersebut berubah menjadi peningkatan toleransi dan sikap saling hormat menghormati. Sehingga dengan adanya toleransi tesebut perubahan dalam bidang ekonomi menjadi berubah karena mereka sudah bisa saling berinteraksi antar umat beragama, sehingga organisasi keagamaan memberikan prioritas pada proyek-proyek pembangunan sosial dan ekonomi (Ricklefs, 1991: 436).

Wanandi (2014: 123) juga mengungkapkan tahun-tahun pertama pemerintahan Soeharto memang beliau lebih memfokuskan dalam memperbaiki dan melakukan beberapa hal yang tepat dalam setidaknya penulis melihat ada tiga hal secara garis besar yang dilakukan oleh Soeharto, pertama, fokus pada kepentingan publik, membuka lapangan pekerjaan terutama di pedesaan, memperbaiki irigasi dan infrastruktur, memberikan perhatian pada kaum petani, dan memperbaiki nasib rakyat kecil. Kedua, memperbaiki pendidikan dengan program pendidikan dasar gratis bagi semua anak, yang mengakibatkan melek huruf dikalangan anak muda hingga 80 persen. Ketiga, memperbaiki infrastruktur kesehatan dasar dengan membangun pusat kesehatan masyarakat sampai di desa-desa 
terpencil, dan melakukan program Keluarga Berencana.

Akan tetapi berbeda dengan hal yang terjadi pada kaum etnis Cina, bahkan sempat terjadi pergolakan dalam bentuk larangan dan lain sebaginya. Bahkan terjadi berbagi insiden anti-china pada masa rezim Orde Baru bahkan kebijakan yang dikeluarkan rezim Orde Baru terhadap warga Cina lebih sistematis dibandingkan kebijakan Orde Lama, karena tentu hal itu berbeda jauh dengan pro terhadap China. Pemerintah Orde Baru berpendapat bahwa keterlibatan warga Cina dalam peristiwa September 1965 merupakan hasil dari tidak berasimilasinya warga Cina dalam masyarakat Indonesia. Oleh sebab itu pemerintah meluncurkan program asimilasi yang sangat gencar. Pemerintah mengeluarkan Instruksi Presiden No. 14 tahun 1967 mengenai pelarangan agama, kepercayaan, dan adat istiadat Cina yang menghalangi ekspresi kehidupan sehari-hari warga Cina. Proses marginalisasi dilakukan dengan cermat. Partisipasi politik dihambat dengan berbagai alasan, termasuk dalam bidang sosial budaya. Pada era ini terdapat pengaruh keamanan dan Departemen Agama yang kadang-kadang ikut campur dalam pelaksanaan ibadah keagamaan khususnya pada bentuk-bentuk yang lebih Cina. Dulunya acara seperti Tahun Baru Imlek, Perayaan Rebutan, atau Festival Kapal Naga adalah acara umum yang menarik penonton dan bahkan pesertanya berasal dari semua komunitas dengan disertai arak-arakan, menebar hadiah, dan membuka arak-arakan besar. Selanjutnya acara keagamaan Cina hanya dilakukan di lingkungan kelenteng atau dalam kediaman keluarga. Selain alasan ketertiban umum, pemerintah berdalih bahwa perayaan seperti Tahun Baru Imlek bukanlah perayaan agama Buda dan oleh karenanya tidak ada alasan yang kuat (Suhandinata, 2009: 135).

Sekalipun terdapat banyak perubahan sosial dan ekonomi di masa Orde Baru, akan tetapi ini semuanya sudah berada dalam pengawasan dan kendalai dari pemerintah, sehingga rakyat juga merasa semakin tertekan dengan semakin ketatnya pengawasan sosial dan ekonomi dari pemerintah, sehingga sekalipun rakyat merasakan kesejahteraan dalam bidang sosial dan ekonomi melainkan itu hanya kesejahteraan semu, karena apa yang mereka peroleh hanyalah untuk kepentingan pemerintah yang mengatasnamakan negara.

Rakyat tidak punya pilihan lain selain mengikuti apa yang diperintahkan oleh pemerintah dengan berada di bawah tekanan pemerintah yang diwakili oleh aparat-aparat pemerintah dalam hal ini TNI dan lain sebagainya. Dengan tekanan tersebut rakyat bekerja dengan keras untuk membangun perekonomian terutama dalam bidang pertaniaan, sehingga dengan hal ini pada masa Orde Baru Indonesia mampu memenuhi kebutuhan beras dalam negeri, dan bahkan mampu untuk mencapai swasembada beras.

Kenyamanan yang diberikan kepada masyarakat akhirnya, masyarakat pun mulai menyadarinya. Terbukti pada tahun-tahun terakhir pemerintahan Soeharto terjadinya berbagai macam krisis itu merupakan akibat dari kebijakan-kebijakan yang dilakukan Soeharto dalam menangani permasalahan negara. Mulai dikuasainya hal-hal yang sifatnya esensial oleh kaum birokrat bahkan oleh keluarganya sendiri atau dikuasainya oleh segelintir orang, sehingga ketika terjadi berbagai macam krisis negara tidak mampu untuk menahannya. Sehingga penderitaan rakyat mulai terasa karena krisis politik, ekonomi, hukum dan sosial terus bertambah pada tahun terakhir Soeharto menjabat sebagai presiden.

Sekalipun dalam menjalankan pemerintahan, Orde Baru bertekad untuk bertujuan untuk menata kehidupan bernegara dengan menjalankan semua kebijakan yang dilandaskan pada demokrasi Pancasila, atau berdasarkan UUU 1945 dan Pancasila atau mengembalikan negara berdasarkan konstitusi. Akan tetapi semua itu hanya digunakan untuk melanggengkan kekuasaannya. Di dalam aplikasinya tidak sesuai dengan apa yang diharapkan dan bahkan dalam pelaksanaanya banyak terjadi penyimpangan dari konsep UUU 1945 dan Pancasila yang menjadi korbannya ialah rakyat kecil. 
Akibat semua ini, terjadi berbagi macam kelemahan dalam berbagai bidang terutama kelemahan dalam bidang ekonomi, bahkan dengan melemahnya perekonomian membawa malapetaka bagi runtuhnya rezim yang telah dibangunnya, semua itu diakibatkan oleh kroni-kroninya. Masyarakat pun ikut menjadi korban akibat tingkah laku kroni dan keluarganya. Karena semua perekonomian yang esensial dipegang atau dimonopoli oleh kroni dan keluarganya. Perekonomian yang dipegang oleh segelintir orang inilah yang menjadi awal malapetaka bagi rusaknya tatanan pemerintahan dan ambruknya negara dalam semua bidang terutma dalam bidang ekonomi dan masyarakat merasakan dampaknya yang luar biasa, dengan naiknya berbagi kebutuhan pokok.

Tidak dipungkiri bahwa dalam pemerintahan Soeharto banyak menimbulkan perubahan dalam berbagai bidang, hal itu yang pernah dirasakan oleh masyarakat sebagaimana yang telah dijelakan sebelumnya, terutama di daerah pedesaan yang dirasakan oleh kaum petani, karena Soeharto sangat memperhatikan rakyat kecil dan kaum petani, karena Soeharto juga bersal dari kaum petani (Wanandi, 2014: 123). Sehingga Soeharto tidak mengherankan jika beliau sangat memperhatikan kaum petani, hal ini juga terbukti dengan meningkatnya hasil pertanian rakyat dan bahkan sampai kepada swasembada beras yang pernah digalakkan oleh Soeharto.

Perubahan yang terjadi dalam selama ini berubah menjadi perubahan yang membuat rakyat menderita karena paraktek KKN. Semua yang telah dibangun dan meraih kepercayaan masyarakat semuanya tidak cukup untuk menolak dan mempertahankan kekuasaan yang presiden Soeharto bangun sekian tahun. Goyahnya keadaan politik dan ekonomi yang menyebabkan runtuhnya pemerintahan Soeharto. Terutama dalam bidang ekonomi yang sangat dirasakan secara langsung oleh rakyat kecil. Hal ini dengan naiknya harga kebutuhan pokok, seperti beras, terigu, minyak goreng, minyak tanah, gula, susu, telur, ikan kering, dan garam mengalami kenaikan yang tinggi, dan bahkan masyarakat harus antri untuk membeli sembakau. Hal inilah yang sangat dirasakan oleh rakyat kecil pada saat itu.

\section{KESIMPULAN}

Kondisi perekonomian yang diwariskan oleh pemerintahan Orde Lama sangat terpuruk, sehingga kebijakan ekonomi yang diambil pemerintah Orde Baru pada waktu itu melakukan penyelamatan terhadap perekonomian nasional. Pemerintah juga melakukan program reformasi dalam pembangunan dalam negeri dan pembangunan ekonomi. Tidak lepas pula dalam kebijakan Soeharto beliau sandarkan kepada keluarga dan kroni-kroninya, sehingga KKN dalam tubuh pemerintah semakin meningkat, karena semua perekonomian yang esensial dipegang atau dimonopoli oleh kroni dan keluarganya

Sekalipun terdapat banyak perubahan sosial dan ekonomi di masa Orde Baru, akan tetapi ini semuanya sudah berada dalam pengawasan dan kendali dari pemerintah, begitu juga meskipun kesejahteraan sosial dan ekonomi meningkat melainkan hanya kesejahteraan semu, semua itu hanyalah untuk kepentingan pemerintah yang mengatasnamakan negara. Rakyat tidak punya pilihan melainkan hanya mengikuti di bawah tekanan pemerintah yang diwakili oleh aparataparat pemerintah begitu pula dalih Pancasila yang digunakan hanyalah untuk melanggengkan kekuasaan.

\section{DAFTAR PUSTAKA}

Aspinall, Edwar, dkk. 2000. Titik Tolak Reformasi Hari-Hari Terakhir presiden Soeharto. Terjemahan. Yogyakarta: LkiS

Ghazali, Effendi. 2004. Comunication of Politics and Politics of Comunication in Indonesia: A Study on Media Performance, Responsibility and Accountability, Nijmegen: Doctoral Thesis Radboud University.

Hadi, D. W dan Kasuma, G. 2012. Propaganda Orde Baru 1966-1980. Verleden, 1 (1): 1-109 
Ricklefs, H.C. 1991. Sejarah Indonesia Modern. Terjemahan. Yogyakarta : Universitas Gajah Mada Press

Tambunan, T. T. H,. 2015. Perekonomian Indonesia Era Orde Lama Hingga Jokowi. Bogor: Ghalia Indonesia (2001). Perekonomian Indonesia. Teori dan Temuan Empiris. Jakarta: Ghalia Indonesia

Sudirman, Adi. 2014. Sejarah Lengkap Indonesia dari Era Klasik Hingga Terkini. Jogjakarta: Diva Press

Suhandinata, Justian. 2009. WNI Keturunan Cina dalam Stabilitas Ekonomi dan Politik Indonesia. Jakarta: Gramedia

Saidi, A. I. 2007. "Indonesia Dalam Dua Orde Sebuah Citra yang Retak". Jurnal Sosioteknologi

Wanandi, Jusuf. 2014. Menyibak Tabir Orde Baru Memoar Politik Indonesia 1965-1998. Jakarta: PT Kompas Media Nusantara 